\title{
EARLY EVALUATION OF NEW SUGARCANE CLONES IN TWO CROP CYCLES AND INTERRELATIONSHIPS AMONG YIELD AND AGRONOMIC TRAITS
}

\author{
(Received: 6.11.2019)
}

\author{
By \\ F. F.B. Abu-Ellail, Hanan Y. Mohamed" and S.M.I. Bachoosh \\ Breeding and Genetics, and *Variety Maintenance Departments, Sugar Crops Research Institute, \\ Agricultural Research Center, Giza, Egypt.
}

\begin{abstract}
Selecting and developing new high-yielding cane varieties is crucial to enhance its production and meet the ever-increasing demands of sugar. Twenty sugarcane clones (genotypes) and one check cultivar were grown in a randomized complete block design, with three replications, at Mattana Agricultural Research Station (latitude of $25^{\circ} 17^{\prime} \mathrm{N}$ and longitude of $32^{\circ} 33^{\prime}$ ), Luxor Governorate, Egypt, during 2017-2018 and 2018-2019. The objective of this study was to evaluate and calculate interrelationships (correlations) among yield and quality traits in plant cane (PC) and $1^{\text {st }}$ ratoon crop (FR) at early clonal selection stage under Upper Egypt conditions. The results showed significant $(\mathrm{p} \leq$ 0.05 ) differences among the genotypes in cane yield and its component traits, sugar yield and quality traits, except for purity percentage. The interaction of genotype $\mathrm{x}$ crop cycle was highly significant for most studied traits $(\mathrm{p} \leq 0.01)$, and insignificant for purity, sugar recovery percentages and sugar yield. Genotype, viz., G.2017-68, showed substantial superiority over the others, recording the highest cane yield. Sugarcane G.2017-30 genotype produced the highest sugar yield/fed, while the lowest was given by G.2017-28. The correlation analysis manifested that the cane diameter, number of stalks per meter and cane height contributed the most in the harvestable cane yield. Different variations among the tested clones were noticed in the studied traits; it ranged from low for (stalk diameter $\mathrm{cm}$; brix\% and purity $\%$ ) medium for (stalk length $\mathrm{cm}$; sucrose $\%$ and sugar recovery\%) to high for (number of stalks per $\mathrm{m}^{2}$; cane yield and sugar yields ton/fed). Based on the performance of the genotypes across the two crop cycles, the selection at the plant cane and $1^{\text {st }}$ ratoon can be recommended at early clonal stage though it cannot be considered sufficient for mid stages.
\end{abstract}

Key words: Correlations, Interrelationships, Early evaluation, Crop cycles, Genotypes, Clones, Sugarcane (Saccharum spp).

\section{INTRODUCTION}

Sugarcane (Saccharum spp. L.) is an important cash crop (Falcon, 1964). In Egypt, sugarcane is grown on 133.7 thousands ha with total annual cane production of 15.3 million tons (Annual Report of Sugar Crops Council, 2019). Plant breeders are continuously endeavoring to improve the genetic potential of yield and sucrose recovery of this crop to meet the demands of an ever increasing population and limitation of cultivated area in Egypt. Sugarcane variety development programmers primarily envisage breeding for high cane yields and high sugar content suitable for specific environmental conditions (Skinner et al., 1987). Sugarcane varieties tend to run out, or decline after some years in a specific area (Khan et al., 2009).
Evaluation of sugarcane clones performance in breeding cane quality attributes decreased time to identify superior clones (Bell et al., 2008). Abu-Ellail et al., (2017) found at early selection stage of sugarcane, that stalk diameter decreased with older crops, while stalk number, cane yield, juice quality traits, and sugar yield increased with older crops. Khan et al., (2012) revealed that higher number of tillers, good cane weight endowed with better pol \% cane and juice purity is the most important characters for consideration in the selection for high sugar yields in sugarcane genotype. Masri et al., (2014) evaluated 30 sugarcane clones including one check cultivar in plant cane and ratoon crops for yield and important characters. Genotype $x$ crops-year interaction was highly significant for 
all traits, except cane yield (ton/fed) and Brix\% which were insignificant. Abu-Ellail et al. (2018) reported significant differences among tested clones for stalk length, stalk diameter, number of stalks/fed, cane yield, Brix \%, sucrose $\%$, purity $\%$, sugar recovery $\%$ and sugar yield in plant cane, $1^{\text {st }}$ ratoon and across crops.

Correlation among phenotypic traits may reflect biological processes that are of considerable evolutionary interest; where correlation can be the result of genetic, functional and physiological or developmental characters (Wagner and Schwenk, 2000). While, Falconer (1989) reported that the association between two or more characters is due to apheliotropic gene action or linkage. Abu-Ellail et al. (2017) showed that the phenotypic correlation between cane yield and its components, viz. stalk diameter, stalk weight and number stalks/fed were highly significant in the positive direction across crop seasons. In plant breeding, correlation coefficient analysis measures the mutual relationship between two plant characters and it determines characters association for genetic improvement of yield and other economic traits (Ahmed et al., 2010). The characters with higher repeatability and genetic gain can be used for selection. The correlations among various characters with yield and their mutual correlation study is important and also gives an insight between the parameters relation (Kang et al., 1983). Masri et al. (2015) reported that phenotypic and genotypic correlation between cane yield and its components, viz. stalk diameter, stalk weight and number stalks/fed were highly significant in the positive direction in plant cane, $1^{\text {st }}$ ratoon and across crops. There was also a positive and significant correlation of cane yield with brix $\%$ and sugar yield. However, insignificant correlation was observed with stalk height at the phenotypic and genotypic level in both plant cane and $1^{\text {st }}$ ratoon crops. The objectives of this study were to: 1 ) Evaluate the yield and quality performance of 20 sugarcane genotypes under two crop cycles; plant cane (PC), and $1^{\text {st }}$ ratoon (FR) at early selection stage, 2) Identify promising clones of sugarcane for further testing, and 3) Calculate correlations among yield and quality traits.

\section{MATERIALS AND METHODS}

The present study was conducted at Mattana Agricultural Research Station (latitude of $25^{\circ} 17^{\prime}$ $\mathrm{N}$ and longitude of $32^{\circ} 33^{\prime}$ ), Luxor Governorate.
The climate of Luxor is classified by the Köppen-Geiger system as desert, where rainfall is about $2 \mathrm{~mm} / \mathrm{year}$, with a mean summer temperature of $32.4^{\circ} \mathrm{C}$, mean winter temperature of $23.2^{\circ} \mathrm{C}$ and relative humidity of $61.6 \%$ during 2017-2018 and 2018-2019. The materials composed 20 genotypes of sugarcane, which were tested along with one check commercial cultivar viz. GT54-9 (Table 1). The genotypes were grown in a randomized complete block design with three replicates. Plot area was $15 \mathrm{~m}^{2}$, including 3 rows of sugarcane of 5-m long, spaced at $1.0 \mathrm{~m}$. Planting was during March 2017 by fifteen 3-budded cane pieces in each row. Field was irrigated right after planting and all other agronomic practices were carried out as recommended. Plant cane was allowed to ratoon after harvest. Both plant cane and its first ratoon crops were harvested at age 12 months. At harvest, a sample of twenty stalks from each plot was collected to determine the following traits:

1. Number of stalks per $\mathrm{m}^{2}$.

2. Stalk length $(\mathrm{cm})$, which was measured from soil surface to the visible dewlap.

3. Stalk diameter $(\mathrm{cm})$, which was measured at the middle part of stalk.

4. Cane yield/fed (ton), which was calculated on plot basis. (one feddan $=0.42 \mathrm{ha}$ ).

5. Brix (total soluble solids \%), which was determined using a Hydrometer.

6. Sucrose percentage, which was determined using automatic Saccharimeter, according to A.O.A.C. (1980).

7. Juice purity $\%$ was estimated as (sucrose\% / brix\% x 100).

8. Sugar recovery\% was calculated according to the formula described by Yadav and Sharma (1980): [Sucrose \% - 0.4 (BrixSucrose \%)] x 0.73

9. Sugar yield/fed (ton) was estimated by multiplying net cane yield/fed (ton) by sugar recovery $\%$.

Separate RCBD and combined analyses of variance of collected data were performed according to Gomez and Gomez (1984). Differences between means were done using the least significant difference test (LSD) at 5\% level of probability. SPSS version 21 was used on windows operating system for assessing the magnitudes of correlation among variables (Spearman's Correlation). Phenotypic ( $r \mathrm{p})$ correlation coefficients and their standard errors were calculated for all the traits according to (Falconer, 1989) as flows: 
Table (1): Sugarcane clones used in the present study and their pedigree.

\begin{tabular}{|c|c|c|}
\hline Ser & Clones & $\begin{array}{c}\text { Hybrid combinations } \\
0 \\
\end{array}$ \\
\hline 1 & G.2017-9 & \multirow{4}{*}{ G2009-18 x CP46-115 } \\
\hline 2 & G.2017-14 & \\
\hline 3 & G.2017-16 & \\
\hline 4 & G.2017-17 & \\
\hline 5 & G.2017-26 & \multirow{3}{*}{ EI266-2 x selfing } \\
\hline 6 & G.2017-28 & \\
\hline 7 & G.2017-30 & \\
\hline 8 & G.2017-33 & \multirow{3}{*}{ CP46-115 x G2009-18 } \\
\hline 9 & G.2017-34 & \\
\hline 10 & G.2017-35 & \\
\hline 11 & G.2017-43 & EI266-2 x CP46-115 \\
\hline 12 & G.2017-44 & \multirow{6}{*}{ EI24-2 x EI266-2 } \\
\hline 13 & G.2017-47 & \\
\hline 14 & G.2017-58 & \\
\hline 15 & G.2017-59 & \\
\hline 16 & G.2017-62 & \\
\hline 17 & G.2017-63 & \\
\hline 18 & G.2017-67 & \multirow{3}{*}{ CP46-115 x EI266-2 } \\
\hline 19 & G.2017-68 & \\
\hline 20 & G.2017-70 & \\
\hline 21 & GT54-9 & Check cultivar \\
\hline
\end{tabular}

$\mathrm{EH}=$ Hwamdia, Egypt; $\mathrm{Cp}=$ Canal point, Florida, USA; G = Giza, Egypt.

$$
\mathbf{r x y}=\frac{b^{2} x y}{\sqrt{b^{2} x \times b^{2} y}}
$$

Where, $r_{\mathrm{xy}}=$ phenotypic correlation coefficient between characters $\mathrm{X}$ and $\mathrm{Y} . \sigma_{\mathrm{xy}}^{2}=$ phenotypic covariance between $\mathrm{x}$ and $\mathrm{y}, \sigma^{2}{ }_{\mathrm{x}}=$ phenotypic variance of $x$ trait, $\sigma_{y}^{2}=$ phenotypic variance of y trait. The phenotypic correlation coefficients were tested for their significance with tabulated r-values at $\mathrm{g}-2$ degrees of freedom, where $\mathrm{g}$ is the number of genotypes.

\section{RESULTS AND DISCUSSION}

Highly significant mean squares (ANOVA table is not presented) were observed among the genotypes for cane and sugar yields and its components, except for purity \%. Crop-year mean squares were also highly significant, except for stalk length and purity\% in crop-year, respectively. Genotype $\times$ Crop-year $(\mathrm{G} \times \mathrm{Y})$ interaction mean squares were significant for most studied traits $(\mathrm{p} \leq 0.01)$, except for purity $\%$, sugar recovery $\%$ and sugar yield, respectively. These results are in line with Tahir et al. (2014), Masri et al. (2014) and Abu-Ellail et al. (2018), who found highly significant mean squares at $\mathrm{P}<0.05$ for stalk length, cane yield and sugar yield, except stalk diameter and stalk number, which were not significant, On the other hand the genotype $\mathrm{x}$ crop mean squares were highly significant $(\mathrm{P}<0.01)$ for the studied characters under this experiment.

\subsection{Performance of genotypes for cane yield and components}

Data presented in Table (2) revealed that the evaluated genotypes varied significantly for stalk length and stalk diameter in the plant cane, $1^{\text {st }}$ ratoon and across crops. The genotype (G.2017-14) recorded the highest mean of stalk length in the plant cane and across crops (259.67 and $259.83 \mathrm{~cm}$ ), while, in the $1^{\text {st }}$ ratoon, the highest mean stalk length $(271.00 \mathrm{~cm})$ was recorded by the genotype (G.2017-17). Across crops; the genotype (G.2017-14) significantly exceeded the overall mean but was lower than that of the check variety G.T.54-9. These results are in harmony with those reported by Masri et al. (2014), who found significant differences among 30 genotypes and their interaction with crops-year for stalk length. Stalk diameter was significantly affected by crops cycles, the genotype (G.2017-63) recorded the highest mean of stalk diameter in the plant cane $(3.10 \mathrm{~cm})$, while in the $1^{s t}$ ratoon, the highest mean stalk diameter $(2.63 \mathrm{~cm})$ was registered by genotype (G.2017-17). Moreover, across crops, the highest mean of stalk diameter $(2.86 \mathrm{~cm})$ was recorded by the genotype (G.2017-63), which surpassed the overall mean, but was lower than that of the check variety G.T.54-9. These results are in agreement with those reported by Jamoza et al. (2014) who reported significant differences among the studied genotypes in stalk diameter at early stage. 
Table (2): Mean performance of sugarcane genotypes for stalk length $(\mathrm{cm})$ and stalk diameter $(\mathrm{cm})$ in plant cane (PC), $1^{\text {st }}$ ratoon (FR) and across crops (AC) during 2017-2018 and 2018-2019 seasons.

\begin{tabular}{|c|c|c|c|c|c|c|}
\hline \multirow[b]{2}{*}{ Genotypes } & \multicolumn{3}{|c|}{ Stalk length $(\mathrm{cm})$} & \multicolumn{3}{|c|}{ Stalk diameter (cm) } \\
\hline & $\mathbf{P C}$ & FR & $\mathbf{A C}$ & $\mathbf{P C}$ & FR & $\mathrm{AC}$ \\
\hline G.2017-9 & 210.33 & 240.00 & 225.17 & 2.55 & 2.40 & 2.48 \\
\hline G.2017-14 & 259.67 & 260.00 & 259.83 & 2.52 & 2.10 & 2.31 \\
\hline G.2017-16 & 259.00 & 253.67 & 256.33 & 2.65 & 2.42 & 2.53 \\
\hline G.2017-17 & 200.00 & 271.00 & 235.50 & 2.76 & 2.63 & 2.70 \\
\hline G.2017-26 & 243.33 & 196.87 & 220.10 & 2.52 & 2.31 & 2.42 \\
\hline G.2017-28 & 201.33 & 247.67 & 224.50 & 2.43 & 2.47 & 2.45 \\
\hline G.2017-30 & 232.67 & 263.67 & 248.17 & 2.49 & 2.37 & 2.43 \\
\hline G.2017-33 & 208.00 & 244.00 & 226.00 & 2.50 & 2.41 & 2.46 \\
\hline G.2017-34 & 220.67 & 262.67 & 241.67 & 2.58 & 2.22 & 2.40 \\
\hline G.2017-35 & 240.33 & 229.67 & 235.00 & 2.56 & 2.30 & 2.43 \\
\hline G.2017-43 & 254.00 & 231.33 & 242.67 & 2.53 & 2.17 & 2.35 \\
\hline G.2017-44 & 200.67 & 233.33 & 217.00 & 2.41 & 2.23 & 2.32 \\
\hline G.2017-47 & 215.67 & 259.00 & 237.33 & 2.43 & 2.17 & 2.30 \\
\hline G.2017-58 & 159.67 & 251.00 & 205.33 & 2.45 & 2.47 & 2.46 \\
\hline G.2017-59 & 251.00 & 243.33 & 247.17 & 2.84 & 2.40 & 2.62 \\
\hline G.2017-62 & 214.33 & 252.00 & 233.17 & 2.49 & 2.60 & 2.55 \\
\hline G.2017-63 & 213.00 & 229.33 & 221.17 & 3.10 & 2.61 & 2.86 \\
\hline G.2017-67 & 243.67 & 228.33 & 236.00 & 2.56 & 2.57 & 2.57 \\
\hline G.2017-68 & 206.00 & 232.67 & 219.33 & 2.40 & 2.36 & 2.38 \\
\hline G.2017-70 & 212.33 & 222.33 & 217.33 & 2.36 & 2.42 & 2.39 \\
\hline GT54-9 & 276.77 & 266.67 & 271.72 & 2.73 & 2.61 & 2.67 \\
\hline Mean & 224.88 & 243.74 & 234.31 & 2.57 & 2.39 & 2.48 \\
\hline C.V \% & 11.4 & 7.3 & 6.1 & 6.8 & 6.4 & 5.6 \\
\hline
\end{tabular}

L.S.D at $5 \%$

Genotypes(G)

Crop-year (C)

$\mathrm{G} \times \mathrm{C}$
23.17

NS

14.76
0.13

0.03

0.18
The means of stalks $/ \mathrm{m}^{2}$ in Table (3) indicated that genotype (G.2017-30) recorded the highest number of stalks $/ \mathrm{m}^{2}$ in the plant cane $(25.67$ stalks $/ \mathrm{m}^{2}$ ), while in the $1^{\text {st }}$ ratoon, the highest mean of stalks $/ \mathrm{m}^{2}\left(31.00 \mathrm{stalks} / \mathrm{m}^{2}\right)$ was registered by genotype (G.2017-9). However, in the across crops, the highest mean number of stalks $/ \mathrm{m}^{2}\left(26.83 \mathrm{stalks} / \mathrm{m}^{2}\right)$ was produced by genotype (G.2017-43). Also, it exceeded the overall mean by $4.86 \mathrm{stalks} / \mathrm{m}^{2}$, but it did not exceed the check cultivar (G.T.54-9). Millable stalk numbers/fed increased from plant cane to 1 st ratoon and it was decreased by increasing more than 3 crops cycles as found by AbouEllail et al., (2018). Cane yields and the $1^{\text {st }}$ ratoon crops were significantly influenced by the interaction between sugarcane genotypes and crop-year. The genotype (G.2017-68) registered the highest cane yield (ton/fed) in the plant cane (56.50 ton/fed), but in the $1^{\text {st }}$ ratoon, the highest cane yield (58.80 ton/fed) was produced by genotype (G.2017-30 and G.2017-26). However, across crops the highest cane yield (56.25 ton/fed) was recorded by genotype (G.2017-68), also it exceeded the overall mean by 9.72 ton/fed and exceed the commercial cultivar G.T.54-9 by 6.17 ton/fed. Similar results were reported by Musa et al. (1997) and Abu-Ellail et al. (2018), who found significant differences among genotypes, where stalk diameter and stalk length were used to assess stalk weight, and these two traits were further combined with stalk number to express cane yield. El-Shafai and Ismail (2006) found significant differences among the tested sugar cane varieties for cane yield. 
Table (3): Mean performance of sugarcane genotypes for number of stalks per $\mathrm{m}^{2}$ and cane yield (ton/fed) in plant cane (PC), ${ }^{\text {st }}$ ratoon (FR) and across crops (AC) during 2017-2018 and 2018-2019 seasons.

\begin{tabular}{|c|c|c|c|c|c|c|}
\hline \multirow[t]{2}{*}{ Genotypes } & \multicolumn{3}{|c|}{ Number of stalks per $\mathbf{m}^{2}$} & \multicolumn{3}{|c|}{ Cane yield (ton/fed) } \\
\hline & $\mathbf{P C}$ & FR & $\overline{A C}$ & $\mathbf{P C}$ & FR & $\overline{A C}$ \\
\hline G.2017-9 & 18.67 & 31.00 & 24.83 & 50.10 & 56.60 & 53.35 \\
\hline G.2017-14 & 17.00 & 27.00 & 22.00 & 43.30 & 49.80 & 46.55 \\
\hline G.2017-16 & 18.33 & 18.00 & 18.17 & 35.50 & 42.00 & 38.75 \\
\hline G.2017-17 & 19.67 & 19.00 & 19.33 & 39.70 & 46.20 & 42.95 \\
\hline G.2017-26 & 22.33 & 22.00 & 22.17 & 52.30 & 58.80 & 55.55 \\
\hline G.2017-28 & 24.00 & 17.00 & 20.50 & 31.30 & 37.80 & 34.55 \\
\hline G.2017-30 & 25.67 & 22.00 & 23.83 & 52.30 & 58.80 & 55.55 \\
\hline G.2017-33 & 19.33 & 20.33 & 19.83 & 45.30 & 51.80 & 48.55 \\
\hline G.2017-34 & 24.33 & 29.00 & 26.67 & 45.03 & 51.53 & 48.28 \\
\hline G.2017-35 & 19.33 & 23.33 & 21.33 & 38.30 & 47.73 & 43.02 \\
\hline G.2017-43 & 25.00 & 28.67 & 26.83 & 52.70 & 53.47 & 53.08 \\
\hline G.2017-44 & 16.00 & 21.33 & 18.67 & 31.30 & 42.67 & 36.98 \\
\hline G.2017-47 & 25.00 & 26.00 & 25.50 & 44.50 & 48.93 & 46.72 \\
\hline G.2017-58 & 14.33 & 18.67 & 16.50 & 38.30 & 44.80 & 41.55 \\
\hline G.2017-59 & 20.33 & 19.00 & 19.67 & 35.50 & 46.20 & 40.85 \\
\hline G.2017-62 & 21.00 & 19.67 & 20.33 & 48.10 & 49.00 & 48.55 \\
\hline G.2017-63 & 18.00 & 21.67 & 19.83 & 35.50 & 47.40 & 41.45 \\
\hline G.2017-67 & 18.67 & 27.00 & 22.83 & 42.23 & 53.13 & 47.68 \\
\hline G.2017-68 & 18.33 & 21.33 & 19.83 & 56.50 & 56.00 & 56.25 \\
\hline G.2017-70 & 18.67 & 23.00 & 20.83 & 43.90 & 49.67 & 46.78 \\
\hline GT54-9 & 28.67 & 35.00 & 31.83 & 48.97 & 51.20 & 50.08 \\
\hline Mean & 20.60 & 23.33 & 21.97 & 43.36 & 49.69 & 46.53 \\
\hline C.V \% & 15.9 & 17.8 & 13.2 & 17.1 & 11.3 & 13.7 \\
\hline \multicolumn{7}{|l|}{ L.S.D at $5 \%$} \\
\hline Genotypes(G) & & & 3.21 & & & 6.30 \\
\hline Crop-year (C) & & & 1.31 & & & 3.28 \\
\hline $\mathbf{G} \times \mathbf{C}$ & & & 2.54 & & & 4.91 \\
\hline
\end{tabular}

\subsection{Performance of genotypes for quality traits and sugar yield}

The results given in Table (4) indicated that brix $\%$ and sucrose $\%$ varied significantly among in the plant cane, $1^{\text {st }}$ ratoon and across crops. Genotype (G.2017-47) recorded the highest mean brix percentage in the plant cane $(22.73 \%)$, while, in the $1^{s t}$ ratoon, the highest mean brix percentage $(20.77 \%)$ was shown by genotype (G.2017-62). However, across crops, clone (G.2017-68) gave (21.46\%). Also it exceeded the overall mean by about $1.29 \%$ and G.T.54-9 by about $0.44 \%$. Similar results were reported by Masri et al. (2014) and Mohamed et al. (2017), they found that the studied sugarcane varieties differed significantly in brix $\%$, sucrose $\%$, pol\%, sugar recovery $\%$, and reducing sugars $\%$ as well as millable cane yield and recoverable sugar yield (tonlfed). Manjunath et al.(2007) found significant differences among genotypes for brix $\%$ and sucrose $\%$, which were increased significantly from plant cane to its ratoon crop. For sucrose percentage, the genotype (G.2017-47) recorded the highest mean sucrose percentage in the plant cane $(14.95 \%)$, while in the $1^{\text {st }}$ ratoon, and across crops, the highest mean sucrose percentage (14.17 and $14.50 \%$, respectively) was recorded by genotype (G.2017-59). It also exceeded the overall mean by $1.43 \%$ and G.T.54-9 by $0.02 \%$. Similar results were reported by Abu-Ellail et al. (2018) who indicated that sucrose content and cane yield were the primary yield components of sugarcane, as considered by the breeder at the early selection stages. The interaction between genotypes and crop-year was significant for sucrose percentage (Table 4). 
Table (4): Mean performance of sugarcane genotypes for brix \% and sucrose $\%$ in plant cane $(\mathrm{PC}), 1^{\text {st }}$ ratoon (FR) and across crops (AC) during 2017-2018 and 2018- 2019 seasons.

\begin{tabular}{|c|c|c|c|c|c|c|}
\hline \multirow[t]{2}{*}{ Genotypes } & \multicolumn{3}{|c|}{ Brix \% } & \multicolumn{3}{|c|}{ Sucrose\% } \\
\hline & PC & FR & $\mathbf{A C}$ & PC & FR & $\mathbf{A C}$ \\
\hline G.2017-9 & 21.33 & 17.53 & 19.43 & 13.74 & 12.38 & 13.06 \\
\hline G.2017-14 & 20.47 & 17.73 & 19.10 & 12.72 & 10.83 & 11.78 \\
\hline G.2017-16 & 20.47 & 20.00 & 20.23 & 12.44 & 13.98 & 13.21 \\
\hline G.2017-17 & 19.22 & 18.30 & 18.76 & 12.09 & 11.48 & 11.79 \\
\hline G.2017-26 & 21.30 & 19.20 & 20.25 & 12.27 & 13.03 & 12.65 \\
\hline G.2017-28 & 19.05 & 18.21 & 18.63 & 12.34 & 11.97 & 12.15 \\
\hline G.2017-30 & 21.07 & 18.42 & 19.74 & 14.49 & 14.16 & 14.33 \\
\hline G.2017-33 & 21.63 & 17.60 & 19.62 & 12.81 & 11.83 & 12.32 \\
\hline G.2017-34 & 20.57 & 19.71 & 20.14 & 13.44 & 12.88 & 13.16 \\
\hline G.2017-35 & 21.25 & 19.47 & 20.36 & 15.95 & 12.05 & 14.00 \\
\hline G.2017-43 & 21.52 & 19.28 & 20.40 & 12.73 & 12.79 & 12.76 \\
\hline G.2017-44 & 20.87 & 18.03 & 19.45 & 12.35 & 12.20 & 12.28 \\
\hline G.2017-47 & 22.73 & 20.07 & 21.40 & 14.95 & 13.23 & 14.09 \\
\hline G.2017-58 & 20.93 & 19.83 & 20.38 & 13.59 & 13.02 & 13.30 \\
\hline G.2017-59 & 22.24 & 19.63 & 20.94 & 14.83 & 14.17 & 14.50 \\
\hline G.2017-62 & 22.13 & 20.77 & 21.45 & 14.48 & 12.13 & 13.31 \\
\hline G.2017-63 & 20.77 & 19.40 & 20.08 & 12.39 & 12.00 & 12.20 \\
\hline G.2017-67 & 22.33 & 19.63 & 20.98 & 12.52 & 13.02 & 12.77 \\
\hline G.2017-68 & 22.36 & 20.57 & 21.46 & 12.44 & 13.80 & 13.12 \\
\hline G.2017-70 & 20.73 & 18.80 & 19.77 & 13.51 & 13.00 & 13.26 \\
\hline GT54-9 & 21.13 & 20.91 & 21.02 & 14.30 & 14.67 & 14.48 \\
\hline Mean & 21.15 & 19.20 & 20.17 & 13.35 & 12.79 & 13.07 \\
\hline C.V \% & 4.6 & 5.1 & 4.2 & 8.3 & 7.2 & 6.1 \\
\hline \multicolumn{7}{|l|}{ L.S.D at $5 \%$} \\
\hline Genotypes(G) & & & 1.11 & & & 1.32 \\
\hline Crop-year (C) & & & 1.01 & & & 0.31 \\
\hline $\mathbf{G} \times \mathbf{C}$ & & & 1.56 & & & 0.86 \\
\hline
\end{tabular}

Results listed in Table (5) indicated that the purity and sugar recovery percentages \% varied significantly among evaluated genotypes in the plant cane, $1^{\text {st }}$ ratoon and across crops. The genotype (G.2017-35) registered the highest mean purity $\%$ and sugar recovery $\%$ in the plant cane $(75.08$ and $10.10 \%$, respectively), while, in the $1^{\text {st }}$ ratoon and across crops, the highest mean purity $\%$ and sugar recovery percentage (76.90, $72.56,9.09$ and $8.87 \%$, respectively) was shown by genotype (G.2017-30). Across crops; the highest genotype (G.2017-30) exceeded the overall mean by $(10.26,7.76,1.48$ and $1.33 \%$, respectively) and G.T.54-9 by $(6.76,3.66,0.2$ and $0.2 \%$, respectively). Similar results were reported by El-Taib (1999) and Masri et al. (2014), who found for sugar recovery percentage significant differences among genotypes, and their interaction between crop-year was not significant. Hagos et al.(2014), who reported that a significant difference for quality parameters was observed among four sugarcane varieties.

Sugar yield (ton/fed) varied significantly among evaluated genotypes in the plant cane, 1 st ratoon and across crops. The genotype (G.2017-30) recorded the highest mean sugar yield (ton/fed) in the plant cane, $1^{\text {st }}$ ratoon, and across crops ; $(4.53,5.35$ and 4.93 ton/fed). The highest genotype in sugar yield (G.2017-30) exceeded the overall mean by $(1.29,1.57$ and 1.42 ton/fed) and it exceeded the check variety G.T.54-9 by (0.39, 0.8 and 0.59 ton/fed), for plant cane, $1^{\text {st }}$ ratoon and across crops, respectively. Abu-Ellail et al. (2017) and Bell et al. (2008) found significant differences among genotypes and insignificant interaction between genotypes and crop-year for sugar yield 
Table (5): Mean performance of sugarcane genotypes for purity\%, sugar recovery\% and sugar yield (ton/fed) in plant cane (PC), $1^{\text {st }}$ ratoon (FR) and across crops (AC) during 2017-2018 and 2018 -2019 seasons.

\begin{tabular}{|c|c|c|c|c|c|c|c|c|c|}
\hline \multirow[t]{2}{*}{ Genotypes } & \multicolumn{3}{|c|}{ Purity\% } & \multicolumn{3}{|c|}{ Sugar Recovery\% } & \multicolumn{3}{|c|}{ Sugar yield\% } \\
\hline & PC & FR & $\mathbf{A C}$ & PC & FR & $\mathbf{A C}$ & $\mathbf{P C}$ & FR & $\mathbf{A C}$ \\
\hline G.2017-9 & 64.42 & 70.61 & 67.21 & 7.81 & 7.53 & 7.67 & 3.91 & 4.26 & 4.09 \\
\hline G.2017-14 & 62.15 & 61.07 & 61.65 & 7.02 & 6.89 & 6.96 & 3.04 & 3.43 & 3.24 \\
\hline G.2017-16 & 60.78 & 69.90 & 65.29 & 6.74 & 8.45 & 7.59 & 2.39 & 3.55 & 2.94 \\
\hline G.2017-17 & 62.93 & 62.72 & 62.82 & 6.74 & 7.39 & 7.07 & 2.68 & 3.41 & 3.03 \\
\hline G.2017-26 & 57.60 & 67.85 & 62.46 & 6.32 & 7.71 & 7.02 & 3.31 & 4.53 & 3.90 \\
\hline G.2017-28 & 64.76 & 65.71 & 65.22 & 7.05 & 6.92 & 6.98 & 2.21 & 2.61 & 2.41 \\
\hline G.2017-30 & 68.77 & 76.90 & 72.56 & 8.66 & 9.09 & 8.87 & 4.53 & 5.35 & 4.93 \\
\hline G.2017-33 & 59.20 & 67.20 & 62.79 & 6.78 & 6.95 & 6.86 & 3.07 & 3.60 & 3.33 \\
\hline G.2017-34 & 65.35 & 65.37 & 65.36 & 7.73 & 7.41 & 7.57 & 3.48 & 3.82 & 3.65 \\
\hline G.2017-35 & 75.08 & 61.89 & 68.77 & 10.10 & 6.63 & 8.36 & 3.87 & 3.16 & 3.60 \\
\hline G.2017-43 & 59.18 & 66.34 & 62.56 & 6.73 & 7.44 & 7.08 & 3.54 & 3.98 & 3.76 \\
\hline G.2017-44 & 59.18 & 67.65 & 63.11 & 6.53 & 7.20 & 6.87 & 2.04 & 3.07 & 2.54 \\
\hline G.2017-47 & 65.78 & 65.94 & 65.86 & 8.64 & 7.66 & 8.15 & 3.85 & 3.75 & 3.81 \\
\hline G.2017-58 & 64.91 & 65.65 & 65.27 & 7.78 & 7.52 & 7.65 & 2.98 & 3.37 & 3.18 \\
\hline G.2017-59 & 66.70 & 72.16 & 69.26 & 8.66 & 8.75 & 8.71 & 3.08 & 4.04 & 3.56 \\
\hline G.2017-62 & 65.44 & 58.42 & 62.04 & 8.34 & 6.33 & 7.33 & 4.01 & 3.10 & 3.56 \\
\hline G.2017-63 & 59.68 & 61.87 & 60.74 & 6.60 & 7.60 & 7.10 & 2.34 & 3.60 & 2.94 \\
\hline G.2017-67 & 56.05 & 66.33 & 60.86 & 6.28 & 7.57 & 6.92 & 2.65 & 4.02 & 3.30 \\
\hline G.2017-68 & 55.63 & 67.10 & 61.12 & 6.18 & 8.10 & 7.14 & 3.49 & 4.53 & 4.02 \\
\hline G.2017-70 & 65.18 & 69.15 & 67.07 & 7.75 & 7.80 & 7.78 & 3.40 & 3.87 & 3.64 \\
\hline GT54-9 & 67.67 & 70.14 & 68.90 & 8.44 & 8.89 & 8.67 & 4.14 & 4.55 & 4.34 \\
\hline Mean & 63.14 & 66.64 & 64.80 & 7.47 & 7.61 & 7.54 & 3.24 & 3.78 & 3.51 \\
\hline C.V \% & 7.4 & 6.3 & 4.9 & 14.1 & 9.0 & 8.3 & 21.0 & 16.5 & 16.5 \\
\hline
\end{tabular}

\section{L.S.D at $5 \%$}

Genotypes (G)

Crop-year (C)

$\mathbf{G} \times \mathbf{C}$

NS
NS
NS

1.38

0.07

NS
0.82

0.32

NS (ton/fed). They concluded that cane yield of most tested genotypes increased in older crops, but crop cycle had no effect on juice quality traits.

\subsection{Interrelationships among yield and agronomic traits}

Phenotypic $\left(r_{p}\right)$ correlation coefficients between all pairs of the studied traits across crops are presented in Table (6). Stalk height gave a positive and highly significant correlation with stalk diameter, cane yield (ton/fed) and sugar yield (ton/fed). Meanwhile, it gave a positive and non-significant correlation with each of brix $\%$, sucrose $\%$, purity $\%$ and sugar recovery\%. A negative and non-significant correlation existed between stalk height and the number of stalks $/ \mathrm{m}^{2}$. James (1971) reported a negative association between stalk diameter and stalk number, however it was positively associated with cane yield. Cane length was positively and substantially correlated with cane yield as reported by Chaudhary et al. (2003). Stalk diameter though had positive and significant association with characters like cane yield and sugar yield at phenotypic level, it showed a positive and non-significant association with brix $\%$, sucrose $\%$, purity $\%$ and sugar recovery\% at phenotypic level. Furthermore, it gave a negative and nonsignificant correlation with the number of stalks $/ \mathrm{m}^{2}$. Results showing positive association of cane diameter with cane yield have already been reported by several investigators (Singh and Sharma, 1997). Number of stalks $/ \mathrm{m}^{2}$ showed positive and significant phenotypic correlations with each of cane yield and sugar 
Table (6): Phenotypic ( $\left.r_{p}\right)$ correlation coefficients among the yield and its components of twenty sugar cane clones across crops (AC) during 2017-2018 and 2018-2019.

\begin{tabular}{|c|c|c|c|c|c|c|c|c|c|}
\hline Traits & & 1 & 2 & 3 & 4 & 5 & 6 & 7 & 8 \\
\hline 1.Stalk height & $\mathrm{r}_{\mathrm{p}}$ & 1.00 & & & & & & & \\
\hline 2.Stalk diameter & $\mathrm{r}_{\mathrm{p}}$ & $0.445^{*}$ & 1.00 & & & & & & \\
\hline 3.Number of stalks $/ \mathrm{m}^{2}$ & $\mathrm{r}_{\mathrm{p}}$ & -0.268 & -0.115 & 1.00 & & & & & \\
\hline 4.Cane yield & $\mathrm{r}_{\mathrm{p}}$ & $0.595^{* *}$ & $0.087 *$ & $0.186^{*}$ & 1.00 & & & & \\
\hline 5.Brix\% & $\mathrm{r}_{\mathrm{p}}$ & 0.179 & 0.105 & -0.10 & 0.276 & 1.00 & & & \\
\hline 6.Sucrose\% & $\mathrm{r}_{\mathrm{p}}$ & 0.207 & 0.283 & 0.095 & 0.201 & $0.605^{* *}$ & 1.00 & & \\
\hline 7.Purity\% & $\mathrm{r}_{\mathrm{p}}$ & 0.252 & 0.357 & 0.073 & 0.048 & -0.001 & $0.757^{* *}$ & 1.00 & \\
\hline 8.Sugar recovery \% & $r_{p}$ & 0.293 & 0.256 & 0.021 & 0.218 & 0.396 & $0.939^{* *}$ & $0.883^{* *}$ & 1.00 \\
\hline 9.Sugar yield & $\mathrm{r}_{\mathrm{p}}$ & $0.651^{* *}$ & $0.213^{*}$ & $0.193 *$ & $0.857^{* *}$ & $0.418^{*}$ & $0.587^{* *}$ & $0.460^{*}$ & $0.647^{* * *}$ \\
\hline
\end{tabular}

$*$, ** Significant at $5 \%$ and $1 \%$ probability levels, respectively.

yield. On the other hand, number of stalks $/ \mathrm{m}^{2}$ had a negative and significant correlation with brix $\%$ at the phenotypic level, it showed a positive and non-significant association with sucrose $\%$, purity $\%$ and sugar recovery\% at phenotypic level. Masri et al., (2015) found that the number of millable canes had negative correlations with all the other traits except cane yield in both crops. A strong negative correlation between the number of millable canes and diameter was recorded. Cane yield (ton/fed) had a positive and highly significant correlations with sugar yield at the phenotypic level. However, such correlations were positive and insignificant with each of brix $\%$, sucrose $\%$, purity $\%$ and sugar recovery $\%$ at the phenotypic level. Our results are in agreement with those mentioned by Sanghera $e t$ al.(2015), who reported that cane yield was correlated positivity with morphological and cane characters. The cane yield, considered as the most important character of sugarcane, had a negative correlation with sucrose $\%$, and purity $\%$ (Masri et al., 2015).

Brix reading showed positive and highly significant correlations with each of sucrose \% and sugar yield at the phenotypic level, while this trait (brix \%) had a negative and nonsignificant correlation with purity\%, but a significant and positive correlation with sugar recovery \%. Chang (1997) evaluated six sugarcane cultivars and indicated that the greatest phenotypic correlations existed among brix $\%$ and sugar content. Sucrose percentage exhibited positive and highly significant correlations with each of purity $\%$, sugar recovery $\%$ and sugar yield at the phenotypic level. Abu-Ellail et al. (2017) found that sucrose content in juice was positively and significantly associated with purity and sugar yield. Purity percentage showed positive and highly significant correlations with each of sugar recovery $\%$ and sugar yield at the phenotypic level. Positive and highly significant correlations exicted between sugar recovery $\%$ and sugar yield at the phenotypic level. Singh et al. (2013) showed significant and positive genotypic correlations between sugar yield and each of cane weight, cane yield, brix $\%$ and sucrose $\%$.

\section{Conclusions}

It may be concluded that some of the evaluated clones could be selected under different crop cycles with higher productivity associated with higher stalk number, stalk diameter and cane and sugar yields. Therefore, these traits could be considered as useful tools during crop breeding procedure in order to make this process more rapid and cheaper. There were variations among the tested clones that may be noticed according to the studied traits; it ranges from low, medium to high. Our results found that clones, G2017-68 (56.25 and 4.02 ton/fed), G2017-9 (53.35 and 4.09 ton/fed), and G201730 (55.55 and 4.93 ton/fed), respectively, produced the highest cane and sugar yields. This indicates that they are of greater promise and can be evaluated in subsequent regional selection programs and at different age levels. A wide scale study is yet needed; therefore, these genotypes were selected for zonal varietal testing trials for further testing at different locations under diverse agro-climatic conditions. 


\section{REFERENCES}

Abu-Ellail F. F. B., El-Taib A. B. A. and Masri M.I. (2017). Broad-sense heritability, genetic correlation and genetic variability of sugarcane yield components at first selection stage. J. Sugarcane Res., 7 (1): $27-34$.

Abu-Ellail F. F. B., El-Taib A. B. A. and Masri M. I. (2018). Performance of new sugarcane clones for yield and its components during two different crop cycles. Indian J. Sugarcane Technol., 33 (01): 26-33.

Ahmed A.O., Obeid A. and Dafallah B. (2010). The Influence of characters association on behavior of sugarcane genotypes (Saccharum Spp) for cane yield and juice quality. World J. Agric. Sci., 6 (2): $207-$ 211.

Annual Report of Sugar Crops Council, (2019): In Arabic 1-50

A.O.A.C. (1980). Official Methods of analysis. Association of official Analytical Chemists, Washington, D.C., USA.

Bell M.J., Halpin N.V. and Garside A.L. (2008). Performance of sugarcane varieties with contrasting growth habit in different row spacing and configurations. Sugarcane Int'l., 26 (1):12-17, 20.

Chang Y.S. (1997). Estimating heritability and correlations among Brix, purity and sugar content in sugarcane using balanced multiple location and year data. Taiwan Sugar, 44(5):18-22.

Chaudhary R.R., Chaudhary N.K. and Sharma R.C. (2003). Path coefficient analysis in sugarcane. J. Inst. Agric. Anim. Sci., 24: 13-19.

El-Shafai A.M.A. and Ismail A.M.A. (2006). Effect of row spacing on yield and quality of some promising sugarcane varieties. Egypt J. Appl. Sci. 21 (11), 32-46.

El-Taib A. B. A. (1999). Stability of yield and quality for some sugarcane genotypes. M.Sc. Thesis, Dept. of Agr., Fac. of Agric., Assiut University, Egypt.

Falcon W.P. (1964). Farmer response to price in a subsistence economy: The case of West Pakistan. Am. Eco. Review. 54(3):580591.

Falconer D. S. (1989). Introduction to Quantitative Genetics. $3^{\text {rd }}$ ed., Longman Scientific \& Technical, (pub.) London. UK, Pp 448.

Gomez K. A. and Gomez A. A. (1984).
Statistical procedures for agricultural Researches. $2^{\text {nd }}$ Ed., John Wiley \& Sons, New York U.S.A., 97-107.

Hagos H., Mengistu L. and Mequanint Y. (2014). Determining optimum harvest age of sugarcane varieties on the newly establishing sugar project in the tropical areas of tendaho, Ethiopia. Adv. Crop Sci. Tech. 2 (5): 156-159.

James N.I. (1971). Yield components in random and selected sugarcane populations. Crop Sci., 11:906-908.

Jamoza J. E., Owuoche J., Kiplagat O. and Opile W. (2014). Broad-sense heritability estimation and correlation among sugarcane (Saccharum spp. hybrids) yield and some agronomic traits in western Kenya. . Int'l. J. Agric. Policy and Res. 2 (1), pp.016-025,

Kang M.S., Miller J.D. and Tai P.Y.P. (1983). Genetic and phenotypic path analysis and heritability in sugar cane .Crop Sci., 23:643-647.

Khan I.A, Bibi S., Yasmin S., Khatri A., Seema N. and Abro S.A. (2012). Correlation studies of agronomic traits for higher sugar yield in sugarcane. Pak. J. Bot., 44:969.

Khan I.A., Dahot M.U., Seema N., Yasmin S., Bibi S., Raza S. and Khatri A. (2009). Genetic variability in sugarcane plantlets developed through in vitro mutagenesis. Pak. J. Biot. 41(1):153- 166.

Manjunath B. L., Wasnik H. M. and Korikanthimath V. S. (2007). Selection of sugarcane varieties for higher yield and recovery in west coast region. J. Farm. Systems-Res. Develop., 13(2): 166-268.

Masri M. I., Shaban Sh. A., El-Hennawy H. H., El-Taib A. B. A. and Abu-El-lail F.F.B. (2014). Evaluation of some sugarcane genotypes for yield and quality traits at the first clonal selection stage. Egypt. J. Appl. Sci., 29(12B): 709-730.

Masri M. I., Shaban Sh. A., El-Hennawy H. H., El-Taib A. B. A. and Abu-El-lail F.F.B.

(2015). Phenotypic and genotypic correlations and path coefficient analysis sugarcane at first clonal selection stage. Egypt. J. Plant Breed, 19(2):297 - 321.

Mohamed Hanan Y., El- Bakry A., Fahmy A. M. and Mehareb E. M. (2017). Yield and quality of sugar cane varieties as affected by potassium silicate and infestation with chilo Agamemnon. J. Biol. Chem. 
Environ. Sci., 12(4): 563-583.

Musa M., Bekele I. and Mohamed M. (1997). The effect of location on three selection parameters in sugarcane varietal trials on plant cane and three ratoons. Proceedings of the West Indies Sugar Technologists Conference, 22-26 Sep.: pp 69-76.

Sanghera G. S., Tyagi V., Kumar R., Thind K. S. and Sharma B. (2015). Genetic variability, association and their dissection through path analysis for cane yield and its component traits in early maturing sugarcane clones. J. Sci. Agric., 5(1):28-34.

Singh P. and Sharma M. L. (1997). Cause and effect of relationship in clonal population of sugarcane. $7^{\text {th }}$ Seventh All India Congress of Cytology and Genetics, India. 25-32.

Singh S. P., Nigam A. and Singh R. K. (2013). Influence of rind hardness on sugarcane quality. Amer. J. Plant Sci., 4, 45-52.
Skinner J. C., Hogarth D. M., WU K. K. (1987). Selection methods, criteria and ondices in sugarcane improvement through breeding. In Heinz DJ. (ed) Elsevier Amsterdam. pp. 409-455.

Tahir M., Khalil H., McCord P. H. and Glaz B. (2014). Sugarcane genotype performance in three environments (based on crop cycle) at Mardan, Pakistan. Ame. J. Experim. Agric., 4(3): 362-375.

Wagner G. P. and Schwenk K. (2000). Evolutionarily stable configurations: Functional integration and the evolution of phenotypic stability. Vol (31):155-217; Max K. Hecht et al. (eds), Kluwer Academic/ Plenum Publishers, New York, USA. 2000.

Yadav R. L. and Sharma R. K. (1980). Effect of nitrogen levels and harvesting dates on quality characters and yield of four sugar cane genotypes. J. Indian, 50 (7): 581-589.

$$
\begin{aligned}
& \text { التقييم المبكر لبعض التراكيب الوراثية الجديدة من قصب الصفات الزراعية في دورتين محصوليتين } \\
& \text { فراج فرغل برعى أبو الليل *حنان يوسف محمد - سعيد مصطفى ابراهيم بقوش }
\end{aligned}
$$

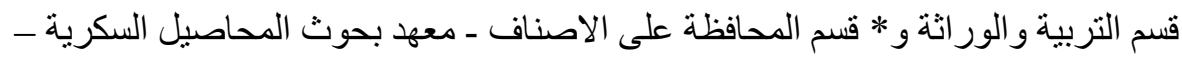

$$
\begin{aligned}
& \text { مركز البحوث الزر اعية ـ الجيزة - مصر. }
\end{aligned}
$$

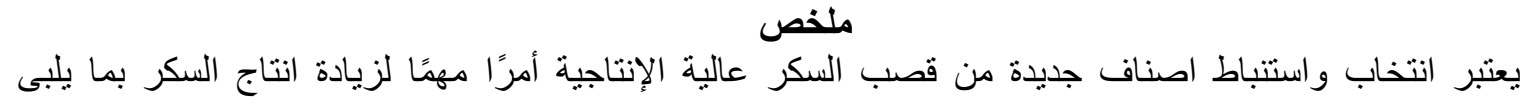

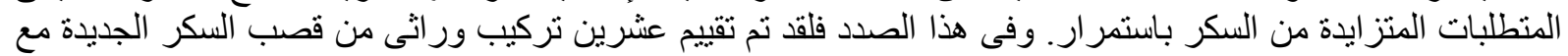

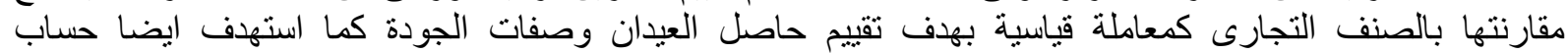
الارتباطات بين صفات كمية المحصول والجودة. في قصب الغرس (PC) ومحصول الخلفة الاولى (FR) في مرحلة

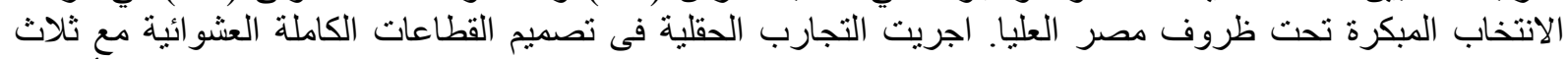

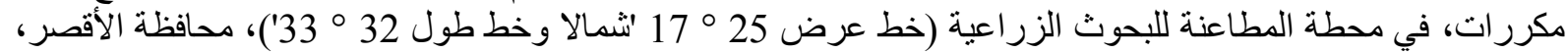

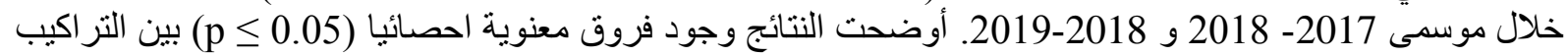

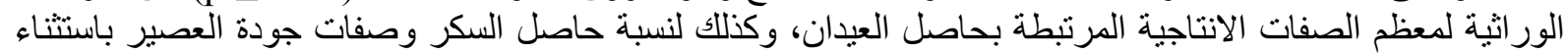

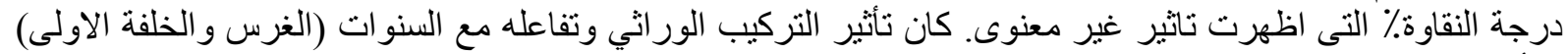

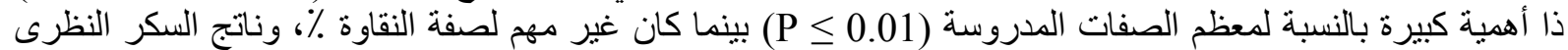

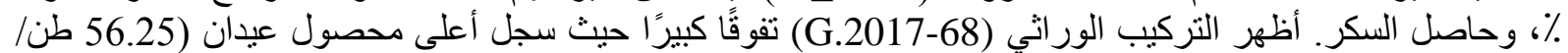

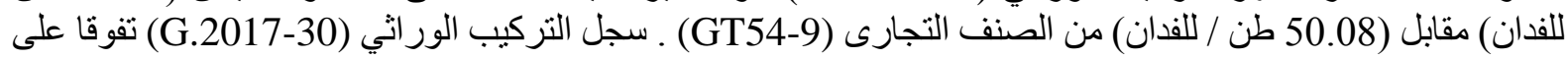

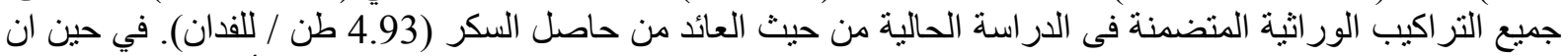

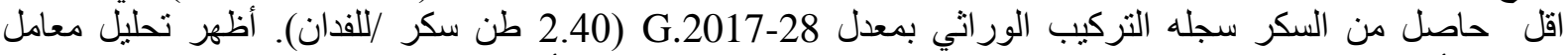

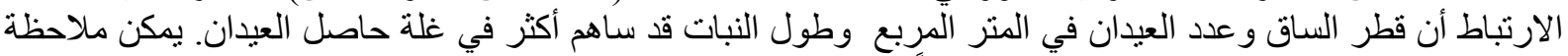

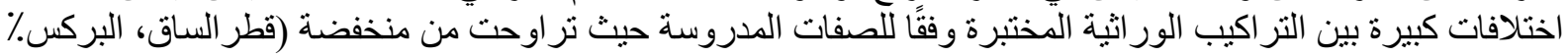

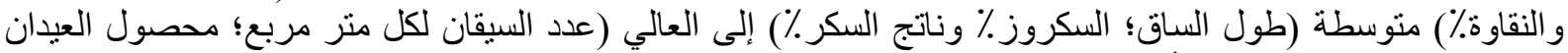

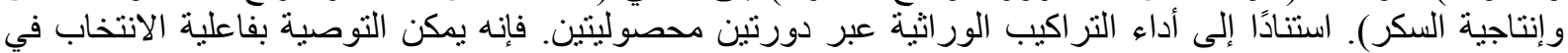

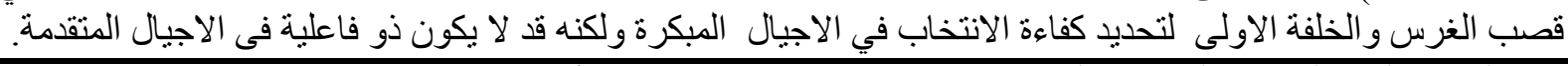

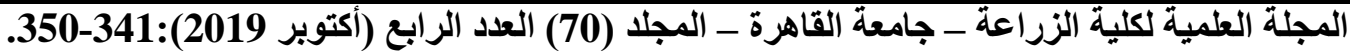

